\title{
IMPLEMENTASI BUDAYA SEKOLAH DALAM PEMBENTUKAN KARAKTER PESERTA DIDIK DI MTS MAMBAUS SHOLIHIN
}

\author{
Rieke Regita Cahyani, Puput Ayu Wulandari, Ida Miftakhul Jannah \\ UIN Sunan Ampel, Surabaya - Indonesia |
}

\begin{abstract}
Abstrak: Pembangunan karakter merupakan salah satu bidang yang sangat penting dalam kehidupan bermasayarakat, berbangsa, dan bernegara. Lembaga pendidikan merupakan salah satu wahana pembangunan karakter. Penanaman nilai-nilai karakter berbasis budaya sekolah dapat dilakukan dengan cara memanfaatkan dan memberdayakan semua lingkungan belajar secara optimal untuk menanamkan, memperbaiki, menguatkan, dan menyempurnakan pendidikan karakter. Penelitian ini bertujuan untuk menjabarkan budaya sekolah yang mendorong terbentuknya karakter pada peserta didik di MTs Mambaus Sholihin. Penelitian ini menggunakan metode deskriptif dengan pendekatan kualitatif. Data dikumpulkan melalui wawancara mendalam, observasi, serta studi dokumen. Hasil penelitian menunjukkan bahwa: 1) Madrasah membentuk karakter peserta didik melalui penerapan budaya sekolah. 2) Budaya sekolah yang diterapkan meliputi etika peserta didik kepada pendidik, budaya ketika memulai dan mengakhiri pelajaran, budaya jujur dan tanggung jawab kepada diri sendiri dan orang lain, 3) Karakter yang terbentuk meliputi disiplin, religius, sikap peduli, jujur, dan tanggung jawab.
\end{abstract}

Keywords: Budaya sekolah, karakter peserta didik

\section{Pemdahuluan}

Pendidikan merupakan usaha yang dilakukan manusia secara sadar, untuk memberikan berbagai pengetahuan kepada seseorang agar lebih cakap dan dewasa, baik lahiriah maupun batiniah. Dengan demikian pendidikan memegang peranan penting terhadap diri manusia dalam mempertahankan hidupnya, baik secara pribadi, sosial kemasyarakatan dan bernegara. Dunia pendidikan Indonesia sekarang ini sangat kritis akan karakter yang dimiliki 
peserta didik. Karakter merupakan sifat-sifat kejiwaan, akhlak, atau budai pekerti yang membedakan seseorang dengan yang lainnya. Sebagaimana tercantum di dalam Undang-Undang No 20 tahun 2003 yang menetapkan bahwa pendidikan adalah usaha sadar dan terencana untuk mewujudkan suasana belajar dan proses pembelajaran agar peserta didik secara aktif mengembangkan potensi dirinya untuk memiliki kekuatan spiritual keagamaan, pengendalian diri, kepribadian, kecerdasan, akhlak mulia, serta keterampilan yang diperlukan dirinya, masyarakat, bangsa dan negara.

Pendidikan karakter merupakan pendidikan yang ditujukan untuk mengukir akhlak melalui proses knowing the good, loving the good, and action the good, yaitu proses pendidikan yang melibatkan aspek koqnitif, emosi, dan fisik sehingga akhlak mulia bisa terukir menjadi habit of the mind, heart, and hands. Pendidikan merupakan proses transformasi budaya dari satu genearasi ke generasi lain, proses pembentukan kepribadian, proses membentuk peserta didik menjadi warga negara yang baik, serta penyiapan tenaga kerja agar output dari dunia pendidikan dapat hidup layak dalam masyarakat. Namun yang terjadi selama ini tidak semestinya, praktek pendidikan selama ini masih berorientasi kepada proses mengajar dan menghimpun informasi keilmuan sebanyak mungkin, tetapi melupakan aspek pendidikan yang fundamental yaitu bagaimana melahirkan generasi yang mampu menjalani hidup dan kehidupan dengan seutuhnya bersandar kepada nilai-nilai Ilahiyah.1

Dalam rangka membentuk karakter peserta didik yang diharapkan, maka lembaga pendidikan dapat melatihnya melalui budaya sekolah. Budaya merupakan produk lembaga yang berakar dari sikap mental, komitmen, dedikasi, dan loyalitas setiap personil lembaga. Budaya merupakan pandangan hidup yang diakui bersama oleh suatu kelompok masyarakat yang mencakup cara

${ }^{1}$ Muhammad Iqbal, Niswanto, dkk, "Budaya Organisasi Sekolah dalam Pembentukan Karakter Peserta Didik pada SMA Negeri 1 Kota Lhokseumawe," Jurnal Magister Administrasi Pendidikan, Vol. 6 No. 4 (November: 2018), 234-235 
berpikir, perilaku, sikap, dan nilai-nilai yang tercermin baik dalam wujud fisik maupun abstrak. Budaya adalah asumsi dasar dan keyakinan di antara para anggota kelompok atau organisasi. Budaya juga dapat dilihat sebagai suatu perilaku, nilai-nilai, sikap hidup, dan cara hidup untuk melakukan penyesuaian dengan lingkungan dan cara memandang persoalan serta pemecahannya.

Eksistensi budaya sekolah memiliki peranan yang sangat penting dalam peningkatan kualitas sekolah. Kondisi ini mengingat bahwa budaya sekolah berkaitan erat dengan perilaku dan kebiasaan warga sekolah untuk melakukan penyesuaian dengan lingkungan, serta cara memandang persoalan dan memecahkannya di lingkungan sekolah, sehingga dapat memberikan landasan dan arah pada berlangsungnya suatu proses pendidikan yang efektif dan efisien. Dengan demikian maka substansi budaya sekolah adalah perilaku, nilai-niali, sikap dan cara hidup warga sekolah yang berusaha mendinamisir lingkungan sekolah untuk mencapai tujuan sekolah. Budaya sekolah yang positif akan memberi warna tersendiri dan sejalan dengan pelaksanaan manajemen berbasis sekolah. Budaya positif tersebut antara lain: budaya jujur, budaya saling percaya, budaya bersih, budaya disiplin, budaya baca, budaya kerjasama, budaya memberi teguran, dan penghargaan. 2

Telah diakui bahwa budaya sekolah menjadi salah satu kriteria penentu mutu atau kualitas pendidikan. Hal ini juga diakui oleh Pamuji dan Prasojo, bahwa budaya sekolah menjadi salah satu faktor penting dalam menentukan keberhasilan mutu pendidikan, khususnya dalam upaya meningkatkan kedisiplinan siswa. Namun demikian, kondisi di lapangan menunjukkan lain. Masih terdapat beberapa sekolah yang belum mampu mengelola budaya sekolah dengan baik, sehingga budaya sekolah yang sudah tertanam sejak lama tidak berjalan dengan baik dan perlahan akan memudar.3

\footnotetext{
${ }^{2}$ Neprializa, "Manajamen Budaya Sekolah," Manajemen Pendidikan Vol. 9 No. 3 (Juli: 2015), 419

${ }^{3}$ Lilik Ardiansyah dan Achmad Dardiri, "Manajemen Budaya Sekolah Berbasis Pesantren di Madrasah Tsanawiyah Ali Maksum, Sewon, Bantul, Yogyakarta," Jurnal Pembangunan Pendidikan, Vol. 6 No. 1 (Juni: 2018), 51
} 
Dalam rangka pembentukan karakter peserta didik melalui budaya sekolah dalam, keteladanan guru menjadi faktor yang paling menentukan berhasil tidaknya program pembentukan karakter di sekolah, keteladanan guru dapat dilihat dari perilaku guru di sekolah atau di luar sekolah, tugas guru di sekolah tidak hanya mentransfer ilmu pengetahuan, tetapi mencangkup pembentukan kepribadian dan karakter siswa sesuai dengan budaya sekolah. Fakta di lapangan yang sering dijumpai di lingkungan sekolah, terutama terkait kedisiplinan guru saat masuk ke dalam kelas pada proses belajar mengajar berlangsung.

Fakta lain yang ditemukan di lapangan masih banyak terdapat peserta didik yang kurang memiliki karakter baik, kurangnya rasa empati terhadap peserta didik serta kurangnya rasa hormat terhadap guru dan pegawai. Hal ini terlihat dari interaksi antar sesama peserta didik, dewan guru, dan pegawai sekolah yang terjadi di lingkungan sekolah dan luar sekolah.4

\section{Metodologi}

Berdasarkan permasalahan yang akan diteliti maka rancangan penelitian ini menggunakan metode deskriptif kualitatif yang bertujuan untuk memberikan gambaran mengenai realita dan faktafakta secara detail dan teliti. Menurut Sugiono, penelitian deskriptif kualitatif adalah sebuah metode yang bertujuan untuk melukiskan atau menggambarkan keadaan di lapangan secara sistematis dengan fakta-fakta dengan interprestasi yang tepat dan data yang saling berhubungan, serta bukan hanya untuk mencari kebenaran mutlak tetapi pada hakekatnya mencari pemahaman observasi, kemudian keadaan di lapangan tersebut dievaluasi.5

Pengumpulan data dilaksanakan pada Bulan AgustusSeptember 2019. Subjek dalam penelitian ini merupakan kepala sekolah, guru, peserta didik, serta stakeholder untuk menggali informasi sesuai dengan fokus masalah penelitian. Teknik pengumpulan data melalui observasi (pengamatan), wawancara, dan studi dokumen. Observasi dilakukan untuk melihat

${ }^{4}$ Muhammad Iqbal, "Budaya Organisasi," 236

${ }^{5}$ Neprializa, "Manajamen Budaya," 421 
implementasi budaya sekolah dalam mendorong terciptanya karakter peserta didik. Wawancara dilakukan untuk mengetahui hal-hal yang lebih mendalam tentang partisipan dalam menginterprestasikan situasi dan fenomena yang terjadi, di mana hal ini tidak bisa ditemukan melalui observasi. Jenis wawancara yang dilakukan yakni wawancara semi terstruktur yaitu wawancara yang lebih bebas dengan tujuan untuk menemukan permasalahan secara lebih terbuka di mana responden diminta pendapatnya.

Studi dokumen dilakukan untuk menggali informasi yang terjadi di masa silam dan untuk memaknai semua dokumen tersebut sehingga tidak sekadar barang yang tidak bermakna. Analisis data dilakukan sesuai dengan teknik analisis data dari Miles dan Huberman yaitu dengan cara pengumpulan data, reduksi data, penyajian data, verifikasi, dan kesimpulan.6 Teknik analisis data yang digunakan adalah analisis data Model Miles Huberman meliputi pengumpulan data, reduksi data, display data, penarikan kesimpulan, dan verifikasi. Proses reduksi data, penyajian data dan penarikan kesimpulan menjadi gambaran keberhasilan secara berurutan sebagai rangkaian analisis yang terkait. Selanjutnya data yang telah dianalisis, dijelaskan dan dimaknai dalam bentuk katakata untuk mendiskripsikan fakta yang ada di lapangan, pemaknaan yang kemudian diambil intisarinya saja.7

Peneliti melakukan pengecekan keabsahan data (credibility) dengan cara triangulasi data untuk menghindari kemungkinan adanya data yang kurang atauu tidak akurat yang diperoleh dalam penelitian. Teknik triangulasi yang dilakukan adalah triangulasi sumber, metode, dan teori. Triangulasi sumber dilakukan dengan membandingkan informasi yang diperoleh peneliti dari masingmasing informan sampai terbukti ada kesamaan dan konsistensi jawaban. Triangulasi metode dilakukan dengan cara membandingkan informasi atau data dengan cara berbeda, yaitu menggunakan metode wawancara, observasi, dan studi dokumen.

\footnotetext{
${ }^{6}$ Hasnadi, "Penerapan Pendidikan Karakter Berbasis Budaya Sekolah di SD Negeri 15 Kota Banda Aceh," Seminar Nasional Bimbingan dan Konseling, 95

${ }^{7}$ Muhammad Iqbal, Niswanto, dkk, "Budaya Organisasi," 237
} 
triangulasi teori dilakukan dengan membandingkan prespektif teori yang relavan untuk menghindari bias individual peneliti atas temuan atau kesimpulan yang dihasilkan.8

\section{Hasil dan Pembahasan}

Sekolah merupakan suatu bentuk organisasi yang mempunyai budaya tersendiri dari sistem yang utuh dan khas. Kekhasan budaya sekolah tidak lepas dari visi dan proses pendidikan yang berlangsung. MTs Mambaus Sholihin mempunyai visi terciptanya manusia yang memiliki kematangan Aqidah Ahlussunnah Wal Jamaah, memiliki kemampuan kademik yang tinggi, yang dapat mempraktekkan mengembangkan dan atau menciptakan Ilmu Pengetahuan dan Teknologi, serta ke Islaman dan berbasis budi pekerti luhur. Dari visi tersebut dapat disimpulkan bahwa MTs Mambaus Sholihin menumbuhkan karakter peserta didik melalui budaya Islami yang mengacu pada visi madrasah.

Suatu sekolah dapat membentuk dan mengatur budaya yang ada, karena pembentukan dan manajemen budaya sekolah yang baik akan mendukung terciptanya sekolah yang efektif.9 Seperti halnya di MTs Mambaus Sholihin, pembentukan budaya sekolah telah ada sejak berdirinya lembaga tersebut, yang mana ditujukan agar sekolah dapat merealisasikan kurikulum berbasis pesantren melalui perilaku Islami yang ditanamkan kepada peserta didik.

Sebuah sekolah memang seharusnya tidak hanya menjadi tempat belajar, namun juga menjadi tempat memperoleh pendidikan, termasuk pendidikan karakter. Sekolah pada hakikatnya bukanlah tempat guru menyampaikan pengetahuan melalui berbagai mata pelajaran saja, namun sekolah merupakan lembaga yang melakukan usaha dan proses pembelajaran yang berorientasi pada nilai. Begitupun MTs Mambaus Sholihin, pendidik tidak hanya difokuskan pada tugas mengajar, namun

\footnotetext{
${ }^{8}$ Hasnadi, "Penerapan Pendidikan," 95-96

${ }^{9}$ Widyaning Rachmawati, Djum Noor Benty, dkk, "Budaya Sekolah Berbasis Keturunan dalam Pembentukan Karaker Peserta Didik," Jurnal Administrasi dan Manajemen Pendidikan Vol. 1 No. 4 (Desember: 2018), 410
} 
pada realitanya seluruh komponen yang ada di sekolah wajib menjalankan budaya sekolah demi tercapainya tujuan dari sekolah tersebut. Pendidik pada dasarnya pemeran utama dalam proses pembentukan karakter. Mereka mentrasformasikan budaya sekolah kepada peserta didik. Contohnya, dengan cara datang tepat waktu sebelum peserta didik tiba di sekolah.

Pembentukan dan pendidikan karakter melalui sekolah adalah usaha mulia yang mendesak untuk dilakukan. Sekolah bertanggung jawab bukan hanya dalam mencetak peserta didik yang unggul dalam ilmu pengetahuan dan teknologi, tetapi juga dalam karakter dan kepribadian. Hal tersebut dapat didukung oleh budaya sekolah. Karena budaya sekolah kondusif memungkinkan dapat meningkatkan prestasi peserta didik serta akan berimplementasi terhadap pembentukan karakter peserta didik. Selain itu, banyaknya tindak kriminal dan kejahatan yang dilakukan anak usia sekolah disebabkan karena semakin rendahnya norma moral sehingga diperlukan suatu pendidikan yang dapat membangun moral dan karakter siswa. Melalui berbagai kegiatan dan pembiasaan yang baik sangat berpengaruh pada karakter siswa, apalagi pembiasaan dilakukan secara rutin di lingkungan sekolah.10

Keunggulan budaya sekolah dapat dilihat dari pihak eksternal dan internal. Pihak internal yaitu peserta didik, guru serta tenaga kependidikan. Bagi peserta didik adalah meningkatkan kesadaran disiplin, meningkatkan ketaqwaan kepada Tuhan YME, lebih rajin, memiliki toleransi yang tinggi, bertanggung jawab dalam tugas, percaya diri, memiliki jiwa kepemipinan dan cinta tanah air. Keuntungan bagi guru yaitu peserta didik yang mudah diarahkan dalam pembelajaran, pribadi guru dan tenaga kependidikan menjadi lebih bertaqwa kepada Tuhan YME karena pembiasaan sehari-hari, peserta didik yang lebih disiplin dalam pengumpulan data yang diminta. Pihak eksternal yaitu orang tua, masyarakat serta dunia usaha dan dunia industry (DU/DI). Bagi orang tua,

${ }^{10}$ Beti Istanti Suwandayani dan Nafi Isbadrianingtyas, "Peran Budaya Sekolah dalam Pembentukan Karakter Anak Sekolah," Seminar Nasional Lembaga Kebudayaan (Edisi 1: 2017), 35-36 
keuntungan yang didapatkan adalah perasaan bangga terhadap peningkatan karakter baik anaknya, mampu membimbing anak dalam lingkungan yang unggul. Bagi masyarakat, keuntungan yang didapatkan adalah timbulnya standart tampilan peserta didik yang seharusnya ada di lingkungan sosial. Sedangkan keuntungan yang didapatkan oleh pihak dunia usaha dan dunia industry (DU/DI) yaitu peserta didik dapat menjadi calon tenaga kerja yang memiliki sikap teladan bagi rekannya.11

Penerapan konsep budaya sekolah sebenarnya tidak jauh berbeda dengan penerapan konsep budaya organisasi lainnya. Jika terdapat perbedaan, mungkin hanya terletak pada jenis nilai yang dikembangkan sehingga menjadi karakteristik dari para pendukungnya. Nilai-nilai yang memiliki peran serta fungsi untuk mengembangkan, melestarikan, dan mewariskan nilai-nilai budaya kepada para siswanya. Budaya sekolah ditandai dengan adanya keberaturan cara bertindak dari seluruh anggota sekolah yang dapat diamati seperti acara ritual tertentu, bahasa yang digunakan, atau simbol-simbol tertentu yang mencerminkan nilai-nilai yang dianut oleh anggota sekolah. Sebagaimana Kompri mengemukakan bahwa budaya sekolah adalah pandangan hidup yang diakui bersama oleh suatu kelompok masyarakat, yang mencakup cara berpikir, perilaku, sikap, nilai yang tercermin, baik wujud fisik maupun abstrak.12

Budaya merujuk pada suatu sistem nilai, kepercayaan dan norma-norma yang diterima secara bersama-sama, serta dilaksanakan dengan penuh kesadaran. Budaya sekolah diarahkan untuk terciptanya karakter peserta didik yang positif. Setiap sekolah mempunyai ciri khas tersendiri dengan budaya sekolahnya, masing masing yang membedakan dengan sekolah lain. Perbedaan ini menunjukan adanya tinggi rendahnya budaya sekolah. Hal ini sejalan dengan Uhar Suharsaputra, bahwa kultur sekolah merupakan kepribadian, organisasi yang membedakan antara satu sekolah dengan sekolah lainnya, bagaimana seluruh anggota

${ }^{11}$ Widyaning Rachmawati, Djum Noor Benty, dkk, "Budaya Sekolah," 412-413

${ }^{12}$ Hasnadi, "Penerapan Pendidikan," 96 
organisasi sekolah berperan dalam melaksanakan tugasnya tergantung pada keyakinan, nilai dan norma yang menjadi bagian dari kultur sekolah tersebut.13

Untuk mengetahui perbedaan tersebut, dapat dilihat dari karakteristik budaya sekolah. Adapun karakteristik budaya sekolah yang harus dipelihara untuk meningkatkan mutu sekolah menurut Saphier dan King ialah meliputi 1) Kolegalitas: iklim kesejawatan yang menimbulkan rasa saling menghormati dan menghargai sesama profesi kependidikan, 2) Eksperimen. Sekolah merupakan tempat yang cocok untuk melakukan percobaan kearah menemukan pola kerja, 3) High expectation. Keleluasaan budaya sekolah yang memberi harapan kepada setiap orang untuk memperoleh prestasi tertinngi yang pernah dicapai, 4) Trust and confident. Kepercayaan dan keyakinan yang kuat merupakan bagian terpenting dalam kehidupan suatu profesi. Budaya sekolah yang kondusif akan memberi peluang bagi setiap orang untuk percaya diri dan memiliki keyakinan terhadap insentif yang diterima atas dasar gagasan baru yang diberikannya untuk organisasi, 5) Tangible and support. Budaya sekolah mendukung lahirnya perbaikan pembelajaran serta mendorong terciptanya pengembangan profesi dan keahlian, 6) Reaching out to the knowledge. Sekolah merupakan tempat pengembangan ilmu secara luas, objektif dan proporsional, pengkajian, pengembangan gagasan baru, penelitian, pengembangan konsep baru semuanya memerlukan pemahaman landasan keilmuan terlebih dahulu, 7) Appreciation and recognition. Budaya sekolah memelihara penghargaan dan pengakuan atas prestasi guru sehingga menjunjung tinggi harga diri guru, 8) Caring, celebration, and humor. Memberi perhatian, saling menghormati, dan memberi penghargaan atas kebaikan guru disekolah adalah perbuatan terpuji. Humor dan saling menggembirakan adalah budaya pergaulan yang sehat, 9) Invloment in decision making. Budaya sekolah yang melibat staf turut serta dalam pembuatan keputusan menjadikan masalah menjadi transparant dan semua staf sekolah

${ }^{13}$ Fitriani, "Budaya Sekolah Meningkatkan Prestasi Akademik," Jurnal Visi Ilmu Pendidikan, 1008 
dapat mengetahui masalah yang dihadapi dan bersama-sama memecahkannya, 10) Protection of wha's important.memlihara dan menjaga kerahasiaan pekerja merupakan budaya sekolah. Budaya sekolah yang baik akan mengetahui mana uang harus dibicarakan dana pa yang harus dirahasiakan, 11) Tradition. Memelihara tradisi yang sudah lama berjalan dan dianggap baik adalah budaya dalam lingkungan sekolah dan biasanya sukar ditiadakan, seperti tradisi wisudah, upacara bendera, penghrgaan atas jasa atau prestasi dan sebagainya, 12) Honest, open communication. Kejujuran dan keterbukaan di lingkungan sekolah dan seharusnya terpelihara, karena sekolah merupakan lembaga pendidikan yang jujur, cerdas, dan terbuka oleh pemikiran baru ataupun oleh perbedaan pendapat.14

Karateristik tersebut merupakan landasan yang dapat dijadikan sebagai acuan atau indikator untuk menentukan bagaimana budaya dalam sekolah. Budaya sekolah sangat penting untuk menentukan efektifitas hubungan interpersonal. Dorongan budaya sangat penting guna mencapai tujuan yang ingin dicapai.

Ajat Sudrajat mengutip Nursyam, setidaknya ada tiga budaya yang dikembangkan di sekolah, yaitu kultur akademik, kultur sosial budaya, dan kultur demokratis. Ketiga kultur ini harus melekat dalam lingkungan sekolah. Kultur akademik memiliki ciri pada setiap tindakan, keputusan, kebijakan, dan opini, didukung dengan dasar akademik yang kuat. Ciri-ciri tersebut bersifat kritis, objektif, analitis, kreatif, terbuka untuk menerima kritik, menghargai waktu dan prestasi ilmiah, memiliki dan menjunjung tinggi tradiri ilmiah, dinamis, dan berorientasi ke masa depan. Sesuai dengan lingkungan MTs Mambaus Sholihin yang mana tidak terpisah dari Pondok Pesantren Mambaus Sholihin. Dalam kesehariannya, mereka menerapkan dua Bahasa wajib yakni Bahasa Inggris dan Bahasa Arab. Sehingga, pada umumnya peserta didik berkomunikasi dua Bahasa tersebut. Mereka banyak mengukir prestasi pada lomba pidato berbahasa Arab. Hal ini sudah menjadi budaya MTs Mambaus Sholihin sebagai sekolah yang unggul di

${ }^{14}$ Ahmad Susanto, (2016), Manajamen Peningkatan Kinerja Guru: Konsep. Strategi, dan Implemntasinya, Jakarta: Kencana,193-194. 
bidang Bahasa. Dengan demikian, kultur akademik lebih menekankan pada budaya ilmiah yang ada di dalam diri seseorang dalam berfikir, bertindak dan bertingkah laku dalam lingkungan kegiatan akademik.

Kultur sosial budaya dibagi menjadi kultur sosial dan kultur budaya. Kultur sosial meliputi suatu sikap bagaimana manusia itu berhubungan dan berinteraksi satu dengan lainnya. MTs Mambaus Sholihin membangun hubungan baik dengan sesama melalui budaya $5 S$ yakni Salam, Senyum, Sapa, Sopan, dan Santun. Budaya 5S merupakan suatu anjuran yang dilakukan seseorang ketika berkomunikasi dan bersosialisasi kepada orang lain. Negara Indonesia terkenal dengan bangsa yang ramah masyarakatnya. Pernyataan tersebut dikenbal sejak masa penjajahan Jepang karena keramahan tersebut dilihat ketika masyarakat Indonesia saling bertemu saling senyum, tegur sapa, dan sedikit menundukkan badan atau kepala. Hal tersebut menunjukkan perilaku sopan kepada orang di sekitar maupun yang lebih tua.

Sedangkan kultur budaya mencakup pengetahuan, kepercayaan, seni, hukum, moral, adat, dan kemampuan serta kebiasaan yang diperoleh dari turun temurun oleh suatu komunitas. Dengan demikiran kultur sosial budaya lebih menekankan pada interaksi yang berhubungan dengan orang lain, alam, dan interaksi yang cakupannya lebih luas lagi yang diperoleh berdasarkan kebiasaan atau turun-menurun. Kultur demokratis tercermin dalam pengambilan keputusan dan menghargai keputusan, serta mengetahui secara penuh hak dan kewajiban diri sendiri, orang lain, bangsa, dan negara. Berdasarkan paparan tersebut, budaya yang harus dikembangkan di sekolah meliputi kultur akademik, kultur sosial budaya, dan kultur demokratis.

Budaya MTs Mambaus Sholihin berorientasi pada nilai-nilai Islami atau karakter religius. Salim mengungkapkan bahwa membudayakan pendidikan melalui nilai-nilai Islami dapat membimbing rohani peserta didik menuju kepribadian yang bermoral/berakhlak, yang mengarah pada pembentukan sifat dan 
watak manusia yang ideal.15 MTs Mambaus Sholihin merupakan madrasah berbasis pesantren. Nilai-nilai kepesantrenanpun tidak luput dimasukkan di lembaga pendidikan tersebut. Hal inilah yang menjadi salah satu pembeda MTs Mambaus Sholihin dengan sekolah pada umumnya. Para siswa merupakan santri Pondok Pesantren Mambaus Sholihin dan hanya beberapa diantaranya bertempat tinggal di Desa Suci yang merupakan lokasi sekolah tersebut.

Identitas dan ciri tersebut merupakan penampakan dari isi dan misi yang didasarkan atas nilai-nilai pendidikan pesantren yang teguh sekaligus luwes dengan perkembangan yang terjadi pada masyarakat. Jati diri dari MTs Mambaus Sholihin sebagai madrasah berbasis pesantren semakin berbeda karena menerapkan ciri khas konvergensi dalam kurikulumnya. Dalam pola ini, madrasah masih mempertahankan muatan local kepesantrenan, disamping mengadopsi Kurikulum Nasional Pendidikan maupun dari Kementrian Agama. Demikian pula karakter kuat madrasah pesantren terlihat dari pola keterpaduan dalam kurikulum dan pengelolaan proses pembelajarannya. Nilai-nilai kepesantrenan dimaksudkan ke dalam kurikulum yang dipadukan dengan proses pembelajaran. Dalam hal ini kebijakan-kebijakan yang ditetapkan baik berkenaan dengan pendidikan, pengajaran maupun kurikulumnya didasarkan pada usaha secara maksimal dari visi dan misi MTs Mambaus Sholihin yang mempunyai otonomi pendidikan.

Dalam rangka mancapai tujuan sekolah, MTs Mambaus Sholihin berusaha agar peserta didik dapat melaksanakan beberapa kegiatan (budaya sekolah) yang mengarah pada pembentukan karakter, diantaranya yaitu:

Pembiasaan 5S setiap pagi sebelum masuk kelas. Peserta didik dibiasakan dengan kegiatan 5S (Salam, Senyum, Sapa, Sopan, dan Santun). Kegiatan semacam ini dilaksanakan dengan tujuan agar terjalin hubungan yang baik antara pendidik dan peserta didik. Salam dalam hal ini buka berarti berjabat tangan saja, namun seperti

\footnotetext{
${ }^{15}$ Hasnadi, "Penerapan Pendidikan,” 96
} 
mengucapkan salam menurut agama dan kepercayaan masingmasing. Senyum ditujuan agar orang lain merasa nyaman ketika berjumpa. Sapa membuat suasana menjadi akrab dan hangat, sehingga lawan bicara akan merasa dihargai. Sopan ketika berinteraksi dengan orang lain, baik sopan berbicara, sopan ketika lewat, dan lainnya. Santun merupakan sikap yang mendahulukan kepentingan orang lain daripada kepentingan dirinya, atau orang yang memberikan haknya untuk orang lain. Sopan santun bisa diartikan sebagai gerak, kata, tindakan dan ucapan yang membuat orang lain merasa dihargai.

Pembiasaan sikap hormat kepada pendidik. Setiap peserta didik membiasakan untuk berdiri secara serentak ketika guru memasuki kelas serta berjabat tangan diawal dan diakhir pembelajaran. Kegiatan ini dilaksanakan sebagai bentuk penghormatan terhadap guru, agar peserta didik memiliki perhatian lebih kepada guru, dan meminimalisir sikap acuh tak acuh dengan adanya kedatangan guru. Selain itu, kegiatan semacam ini merupakan implementasi dari Kitab Ta'lim Muta'alim yang berisi tata krama kepada guru.

Pembiasaan berdoa sebelum dan sesudah proses pembelajaran serta pembiasaan sholat dhuhur berjamaah. Semua warga sekolah membiasakan untuk sholat dhuhur berjamaah. Hal ini ditujukan untuk meningkatkan ketaqwaan kepada Sang Pencipta dengan cara bersyukur karena masih bisa menjalani aktivitas pendidikan.

Pembiasaan nadhom Imrithi ketika sebelum dan sesudah proses pembelajaran. Dari seluruh peserta didik diwajibkan untuk bisa menghafal Imriti, dan pada akhir kelas IX melaksanakan wisuda Imrithi yang dihadiri oleh wali murid. Kegiatan ini dilatar belakangi karena madrasah terintegrasi dengan Pesantren Mambaus Sholihin. Sehingga kurikulum yang digunakan diselaraskan dengan pembelajaran di pesantren. Adapun mata pelajaran khusus diantaranya yaitu Nahwu (Matan AlJumhuriyah/Nadhom Imrithi), Shorof (Al-Amtsilah AtTasyrifiyah/Nadhom Maqsud), I'lal (Qawaidu I'lal/Ghoyatul Amal), Hadist (Al-Arbain Nawawi/ At-Tarhib Wa Targibh), Akhlaq (AlAkhlaq lil Banin/Banat/Ta'lim Mutaallim), Fiqh (Matan Ghoyah Wat 
Targhib), Tauhid (Al- Aqidahtul Islamiyah), Tajwid (Tuhfatul Athfal/Hidayatul Mustafidh), Faroid (Iddatul Faroidh).

Pembiasaan mengambil dan mengembalikan jurnal serta absensi kelas. Setiap peserta didik diberikan tanggung jawab untuk mengambil jurnal dan absensi ketika sebelum memulai pembelajaran dan mengembalikan ketika pelajaran selesai secara bergiliran atau terjadwal. Hal ini ditujukan untuk melatih kedisiplinan, sikap tanggung jawab di dalam diri peserta didik serta melatih agar lebih peduli dan sigap terhadap kebutuhan guru.

Pembiasaan menulis dibuku ijin ketika keluar kelas. Setiap peserta didik membiasakan untuk ijin ketika meninggalkan pelajaran di tengah proses pembelajaran berlangsung. mereka mempunyai buku ijin yang di dalamnya terdapat kegiatan apa yang akan mereka lakukan, lama waktu ijin, serta paraf pemberi ijin. Adapun yang bertugas memberikan ijin merupakan guru kelas dan pengurus OSIS yang ditugaskan secara terjadwal. Kegiatan semacam ini ditujukan untuk mengkondisikan ketertiban. Selain itu, agar peserta didik tidak sering meninggalkan pelajaran dan bersikap jujur untuk apa yang akan dia lakukan.

Dari beberapa budaya sekolah yang ditanamkan oleh madrasah menunjukkan bahwa budaya sekolah merupakan pengetahuan dan hasil karya cipta komunitas sekolah yang berusaha ditransformasikan kepada peserta didik, dan dijadikan pedoman dalam setiap tindakan komunitas sekolah sehingga menciptakan warana kehidupan sekolah yang dapat dijadikan cermin bagi siapa saja yang terlibat. Hal ini sesuai dengan Departemen Pendidikan Nasional dalam buku pengembangan kurikulum sekolah menjelaskan bahwa budaya sekolah memiliki dua bagian, yaitu bagian yang dapat diamati dan sebagian yang tidak teramati. Bagian yang teramati seperti arsitektur, tata ruang, interior, upacara, gambar, bendera, peraturan, symbol, logo, sopan santun, dan cara berpakaian. Bagian yang tidak dapat diamati secara jelas berintikan norma perilaku.16

${ }^{16}$ Muhammad Iqbal, Niswanto, dkk, "Budaya Organisasi,” 237 
Pembentukan karakter peserta didik melalui budaya madrasah yang diterapkan MTs Mambaus Sholihin ini sesuai dengan pernyataan bahwa dalam pendidikan karakter sangat penting dikembangkan nilai-nilai etika seperti kepedulian, kejujuran, keadilan, tanggung jawab, dan rasa hormat terhadap diri dan orang lain bersama dengan nilai-nilai kinerja pendukungnya seperti ketekunan, etos kerja yang tinggi, kerja keras, dan kegigihan sebagai basis karakter yang baik. Sekolah harus berkomitmen untuk mengembangkan karakter siswa berdasarkan nilai-nilai dimaksud, mendefinisikan dalam bentuk perilaku yang dapat diamati dalam kehidupan sekolah sehari-hari.17

Seluruh pembiasaan yang diterapkan di madrasah telah diperkenalkan kepada peserta didik sejak mereka mengikuti MOS (Masa Orientasi Siswa). Sehingga dalam pelaksanaannya dapat berjalan dengan maksimal.

\section{Kesimpulan}

MTs Mambaus Sholihin merupakan sekolah berbasis pesantren yang telah menerapkan budaya sekolah, di mana segala aktivitas dilakukan berdasarkan nilai-nilai pesantren. Proses pembentukan karakter peserta didik melalui pelaksanaan budaya sekolah di MTs Mambaus Sholihin diawali dengan pembiasaan kegiatan setiap hari yang ditujukan kepada peserta didik dengan acuan visi madrasah. Adapun kegiatan tersebut meliputi pembiasaan 5S setiap pagi sebelum masuk kelas, pembiasaan sikap hormat kepada pendidik, pembiasaan berdoa sebelum dan sesudah proses pembelajaran serta pembiasaan sholat dhuhur berjamaah, pembiasaan mengambil dan mengembalikan jurnal serta absensi kelas, dan pembiasaan menulis dibuku ijin ketika keluar kelas. Hasil akhir yang didapatkan peserta didik melalui pembiasaan dari budaya sekolah yang ada merupakan nilai-nilai karakter yang terinternalisasikan dan terbentuk dalam diri peserta didik.

${ }^{17}$ Melisa Agustrianti, Feri Wahyudi, dkk, "Manajemen Peserta Didik Berbasis Pesantren dalam Pembentukan Karakter di Madrasah Aliyah Nurul Huda Pringsewu Tahun Pelajaran 2016/2017,” 35 
Adapun nilai-nilai karakter yang terbentuk dengan adanya budaya tersebut diantaranya sikap disiplin, jujur, tanggung jawab, rasa hormat, sikap peduli, dan perilaku Islami. Sikap disiplin, dan tanggung jawab ditunjukkan pada saat pengambilan dan pengembalian jurnal dan absensi kelas, sikap jujur ditunjukkan ketika peserta didik menulis ijin pada saat keluar kelas, sikap hormat ditunjukkan ketika peserta didik berdiri dan berjabat tangan pada saat sebelum dan sesudah pembelajaran, sikap peduli ditunjukkan ketika peserta didik menyiapkan keperluan guru di kelas, dan perilaku Islami ditunjukkan dengan berdoa sebelum dan sesudah pembelajaran serta melaksanakan sholat dhuhur berjamaah.

Berdasarkan implementasi budaya sekolah MTs Mambaus Sholihin dapat ditarik kesimpulan bahwa pelaksanaan budaya sekolah tentu saja tidak jauh dari kata kekurangan baik dari segi pelaksana maupun bentuk kegiatan. Hal yang manjadi penghambat salah satunya merupakan peserta didik, yang mana sebagian besar merupakan santri Mambaus Sholihin. Kegiatan pesantren hingga larut malam mengakibatkan kurang disiplinnya peserta didik, banyak dari mereka yang tertidur di kelas dan tidak mengindahkan guru yang datang. Namun, dengan adanya budaya 5S karakter peserta didik bisa lebih baik untuk menghargai guru dan sesama

Untuk dapat melaksanakan budaya sekolah yang maksimal, maka dapat dimulai dengan keberadaan pemimpin sekelompok orang yang memiliki kesadaran, kemauan serta komitmen untuk mengembangkan gagasan-gagasan baru yang akan dirumuskan dalam visi dan misi sekolah. Kemudian dilakukan identifikasi terhadap nilai, asumsi, serta artifak fisik yang ada sebagai bahan dalam menyusun rancangan pengembangan kultur sekolah.

\section{References}

Neprializa. “Manajamen Budaya Sekolah.” Manajemen Pendidikan Vol. 9 No. 3 (Juli: 2015). 419-429 
Hasnadi. "Penerapan Pendidikan Karakter Berbasis Budaya Sekolah di SD Negeri 15 Kota Banda Aceh." Seminar Nasional Bimbingan dan Konseling. 93-98

Rachmawati, Widyaning, Djum Noor Benty, Dkk. “Budaya Sekolah Berbasis Keturunan dalam Pembentukan Karaker Peserta Didik." Jurnal Administrasi dan Manajemen

Pendidikan Vol. 1 No. 4 (Desember: 2018), 410-418

Istanti, Beti Suwandayani Dan Nafi Isbadrianingtyas. "Peran Budaya Sekolah dalam Pembentukan Karakter Anak Sekolah," Seminar Nasional Lembaga Kebudayaan (Edisi 1: 2017), 34-41

Iqbal, Muhammad, Niswanto, dkk. "Budaya Organisasi Sekolah Dalam Pembentukan Karakter Peserta Didik pada SMA Negeri 1 Kota Lhokseumawe." Jurnal Magister Administrasi Pendidikan, Vol. 6 No. 4 (November: 2018), 234241

Susanto, Ahmad. Manajamen Peningkatan Kinerja Guru: Konsep. Strategi, dan Implemntasinya (Jakarta: Kencana, 2016)

Fitriani. "Budaya Sekolah Meningkatkan Prestasi Akademik." Jurnal Visi Ilmu Pendidikan. 1006-1017

Agustrianti, Melisa, Feri Wahyudi, dkk. "Manajemen Peserta Didik Berbasis Pesantren dalam Pembentukan Karakter di Madrasah Aliyah Nurul Huda Pringsewu Tahun Pelajaran 2016/2017." 32-41

Ardiansyah, Lilik dan Achmad Dardiri. "Manajemen Budaya Sekolah Berbasis Pesantren di Madrasah Tsanawiyah Ali Maksum, Sewon, Bantul, Yogyakarta." Jurnal Pembangunan Pendidikan. Vol. 6 No. 1 (Juni: 2018), 50-58 